\title{
Use of the ODARA by police officers for intimate partner violence: Implications for practice in the field
}

\author{
Dale Ballucci, ${ }^{*}$ Mary Ann Campbell, ${ }^{\dagger}$ and Carmen Gill ${ }^{\ddagger}$
}

\begin{abstract}
Despite research demonstrating the validity of the Ontario Domestic Assault Risk Assessment (ODARA) for appraising risk of subsequent intimate partner violence, gaps remain with regard to its actual use by police officers in the field. The primary goals of the current study were to assess the rate at which the ODARA was used by police officers for intimate partner violence (IPV) in the Canadian context and to identify factors associated with its use. The current study used 142 randomly selected police files meeting criteria for IPV from three police agencies in an Atlantic Canadian province, following province-wide training on domestic violence and the ODARA. The ODARA was used by police in $60.3 \%$ of cases, though more commonly when physical violence was present at index (70\%). Significant ODARA use variation was noted across the three police agencies. ODARAs were more likely administered when the suspect was using drugs/alcohol $(76.4 \%)$, the incident was between parties in a current intimate relationship (67.0\%), when physical violence occurred in the index event $(70.6 \%)$, and when a weapon was used $(84.2 \%)$. Decisions to arrest and recommend charges to the prosecutor were predicted by higher ODARA total scores, above and beyond the influence of the police organization, suspect/victim characteristics, and incident context variables. Results are discussed in the context of police discretion/decision-making and the need for stronger implementation and policy use guidelines for risk appraisal by police officers, which includes a better understanding of IPV and the ODARA.
\end{abstract}

Key Words Police decision-making; risk assessment; police discretion.

\section{INTRODUCTION}

The expansive role of police in responding to intimate partner violence (IPV) has resulted in various initiatives such as specialized units, domestic violence courts, and the mandatory use of risk assessment tools such as the Ontario Domestic Assault Risk Assessment (ODARA; Hilton et al., 2004). Despite research demonstrating the validity of the ODARA for appraising risk of subsequent intimate partner violence (Hilton \& Harris, 2009; Jung \& Buro, 2017), gaps remain with regard to its actual use by police officers in the field (Lauria et al., 2017). Studies are needed to examine how formalized risk assessments are used by responding officers and under what conditions they are more likely to use them (Ariza et al., 2016; Campbell et al., 2018) to inform policy and practice.

To better understand police responses, we investigated how often and in what context Canadian police officers relied on the ODARA in IPV cases. Our analysis details the rate at which the ODARA was used by police officers and the factors associated with its use in IPV calls to uncover the conditions that impact police officers' decisions to complete the ODARA. The ODARA was used most frequently in cases when physical evidence of the abuse was present. We also found that police officers did not always complete the ODARA, even in cases where the incident met the IPV definition. Our findings contribute to the limited studies on the use of the ODARA and offer important policy insights on how to increase police officers' use of the tool.

Our paper proceeds with a literature review and a discussion of the challenges of risk tools in policing. Our analysis is organized in two sections: the administration and legal process. We then discuss the impact of our work and the areas in need of future research.

\footnotetext{
Correspondence to: Dale Ballucci, Social Science Centre, Room 5403, 1151 Richmond St., London, ON N6A 5 C2.

E-mail: dballucc@uwo.ca

To cite: Ballucci, D., Campbell, M. A., \& Gill, C. (2020). Use of the ODARA by police officers for intimate partner violence: Implications for practice in the field. Journal of Community Safety and Well-Being, 5(3), 91-102. https://doi.org/10.35502/jcswb. 150

(C) Author(s) 2020. Open Access. This work is distributed under the Creative Commons BY-NC-ND license. For commercial re-use, please contact sales@sgpublishing.ca.
}

g.PUBLISHING Published by SG Publishing Inc. CSKA Official publication of the Community Safety Knowledge Alliance. 


\section{Why Use Risk Assessment Tools in IPV Cases?}

In the context of IPV, the main purpose of risk assessment is to improve protection for individuals who are experiencing IPV and to provide risk management strategies for those individuals who present higher risk of inflicting potential harm (Hoyle, 2008). There are various marked benefits to utilizing risk assessment instruments in cases of violent crimes, specifically within incidents of IPV. For example, risk assessment can help identify high-risk situations and lead to informed response strategies (Bonta \& Andrews, 2017; Canales et al., 2013). It also helps raise awareness about the risks that IPV incidents carry and provides a means for consistently and accurately flagging high-risk offenders (Canales et al., 2013; Department of Justice Canada, 2014). Furthermore, risk assessment allows criminal justice personnel to appraise the level of danger that a victim faces and should guide professionals in how best to create an informed, proactive risk management plan rather than relying on reactive responses to IPV incidents (Canales et al., 2013).

In court, risk assessment provides evidence judicial personnel can use to make informed decisions within the criminal justice system pertaining to an offender's level of risk (Milgram et al., 2015). It further provides a common language for professionals to use when discussing risk and risk mitigation (Canales et al., 2013). More importantly, when professionals deviate from the risk appraisal generated by evidence-based risk assessment instruments, the judgments rendered tend to be less accurate in their capacity to predict future criminal behaviour (Chappell et al., 2013; Guay \& Parent, 2018; Wormith et al., 2012).

Despite the numerous benefits that risk assessment provides, there are a number of concerns with the use of these tools. The concept of "risk" is ambiguous, and there is little consensus in the empirical and theoretical literature on what is meant by risk within the context of IPV (Kropp, 2004). The operationalization of "risk" as a construct and the tools used to appraise this risk can vary depending on the context in which they are being used (e.g., police vs. forensic mental health setting; pre-trial detention vs. institutional security placement) and by whom they are being used (e.g., mental health professional, police, victim support services), since these tools are designed to be practical and relevant for those using them (Ariza et al., 2016; Hoyle, 2008; Kebbell, 2019; Kropp, 2004).

The training required to accurately complete risk assessments is also a concern in the policing context (Ariza et al., 2016; Belfrage et al., 2012; Bowen, 2011; Messing \& Thaller, 2013; Storey et al., 2014; Ward-Lasher et al., 2017). Often, the tools take time to complete and require information that is not readily available to police or is not easily attainable (Hoyle, 2008; Storey et al., 2014). From a police perspective, training is essential to ensure that police officers are accurately and appropriately implementing risk assessment tools, yet various studies have concluded that training for police officers on IPV generally is limited, let alone training on how to conduct risk assessment within the IPV context (DeJong et al., 2008; Gover et al., 2011; Poon et al., 2014; Robinson et al., 2016; Spivak et al., 2020; Tatum \& Pence, 2015). By examining how risk assessment tools are used, guidelines can be implemented to improve their utility (Spivak et al., 2020).
Finally, and arguably most importantly, police officers hesitate to use risk assessment tools within the context of IPV partly because it reduces their discretionary power (Ballucci et al., 2017; Hoyle, 2008, Kane, 1999; Gover et al., 2011). The lack of training for frontline officers in many elements of risk assessment, such as diagnosis and treatment (Ariza et al., 2016), may also contribute to their frustration with risk assessment tools, particularly given that many officers are receptive to using such tools if they receive adequate training on them (Campbell et al., 2018; Robinson et al. 2018). Research has also found that police officers' understanding of IPV impacts whether they will use a risk assessment tool (Gill et al., 2019; Robinson et al., 2016).

Despite the prevalence of risk assessment tools in correctional decision-making, their presence in policing is relatively new. The decision-making practices prior to the advent of risk assessment tools, however, offer strong evidence for their mandatory implementation. In the absence of risk assessment tools, police officers used their subjective judgment and experience to assess risk. Police officers most commonly respond to incidents of IPV without a risk assessment tool, instead taking into consideration the characteristics of the incident (Tatum \& Pence, 2015; Dawson \& Hotton, 2014; Poon et al., 2014; Durfee \& Fetzer, 2016; Kane, 1999). These characteristics tend to include situational, offender, and victim factors. Much of the literature suggests, for example, that serious assaults resulting in victim injury and incidents involving a weapon have been found to increase the likelihood of arrest (Poon et al., 2014; Dawson \& Hotton, 2014; Tatum \& Pence, 2015). Prior criminal history is another key determinant in arrest decisions made by police officers in IPV cases (Dawson \& Hotton, 2014; Tatum \& Pence, 2015; Poon et al., 2014).

Extra-legal factors also shape police officers' responses to IPV. Police officers, for example, are more likely to make an arrest when a child is present at the scene (Tatum \& Pence, 2015). Although the impact of gender and race are less conclusive in the literature, studies have found that women are less likely to be arrested in IPV incidents than men (Johnson \& Conners, 2017; Poon et al., 2014), and that Indigenous women are more likely to be arrested than white women (Johnson \& Conners, 2017; Poon et al., 2014). This finding is true even in cases where the woman may not be the aggressor, due to dual charging policies (Poon et al., 2014). In the absence of a risk assessment tool, the characteristics of the police officers themselves, such as gender and experience level, play a role in how they decide to respond to an IPV call (Dejong et al., 2008; Gracia et al., 2014). Studies also show that police agency resources, training practices, and the policing philosophy impact decision-making by police officers (Dawson \& Hotton, 2014; DeJong et al., 2008). Furthermore, charging practices vary significantly across Canada, demonstrating that contextual factors influence police decision-making when risk assessment tools are not employed in this process (Dawson, \& Hotton, 2014).

Police attitudes towards and perceptions of IPV also play a significant role in how they respond to these calls (Ballucci et al., 2017; Gill et al., 2019). Officers hold problematic views of IPV calls for service. Some police officers oversimplify the IPV experience, blame the victim, have patriarchal attitudes towards women, and presume that the victim will not cooperate (DeJong et al., 2008). These preconceptions often 
result in failure to issue a warrant for arrest (DeJong et al., 2008). Male police officers who score high in sexism show a preference for conditional law enforcement in cases of IPV (Gracia et al., 2014). Further to this point, many officers do not view sexual abuse as a form of IPV, which results in a decision not to respond to these calls with as much frequency (Durfee \& Fetzer, 2016; Johnson et al., 1994). While this is troubling, progressive policing philosophy and the gender of the officer have been found to increase enlightened views of IPV and impact responses in a positive way (DeJong et al., 2008).

The positive impacts of informed decision-making and risk assessment in police responses to IPV are supported in the literature. The level of risk has been shown to be an important factor in determining whether or not police will act on the complaint and whether or not they will apply for an intervention order in cases of IPV (Trujillo \& Ross, 2008). Similarly, Belfrage et al. (2012) found that police officers' risk assessments often influenced their decision-making in terms of risk management (Belfrage et al., 2012). Informed police response, through the use of risk assessment tools, could reduce offending and increase victim satisfaction with the police (Messing et al., 2014). Victim-related factors, such as their characteristics, level of fear, and vulnerability, also shape police decisions (Trujillo \& Ross, 2008). For example, Storey and Strand (2017) found that in cases with female victims, officers' risk management recommendations were related to the presence of victim vulnerability factors, as well as the overall identified offender risk level (Storey \& Strand, 2017). The consideration of victim-specific factors increases the complexity of police decision-making in response to IPV.

As the literature reflects, there are challenges to implementing and ensuring proper use of risk assessment tools by police officers. Despite these challenges, however, studies overwhelmingly conclude that positive change can result from standardized responses that involve risk assessment practices. Risk tools identify the factors and indicators for IPV predictive of escalation and danger that are not commonly known to police officers. Risk assessment tools provide the knowledge police officers require to make better-informed decisions that can ultimately result in more effective responses to IPV and better protect victims and the community. With the appropriate training, risk assessment tools can decrease bias, provide structure for discretionary decision-making, and increase standardized practices, benefiting police officers nationwide by improving the uptake of such tools in the field (Gover et al., 2011; Campbell et al., 2018)

\section{METHOD}

\section{Sample}

The sample used in the current study is a sub-sample of data from a larger project. The current data represents police use of the ODARA in the year 2015. The ODARA is a score-based risk assessment instrument developed specifically for police officers. It consists of 13 items, including police and criminal record information, index incident factors, relationship factors, assault history, indications of substance abuse, and barriers to victim support (Hilton et al., 2010). The data was collected following province-wide training on domestic violence dynamics and risk factors, the importance of risk appraisal for informing police and community responses, and the use of the ODARA itself by representatives of the instrument's developers. Thus, most officers responding to the calls for service used in the current study should have been knowledgeable about IPV in general, informed about organizational policy on the use of the ODARA, and educated with regard to how to score the ODARA.

The sample consisted of 142 individual police files involving suspects of IPV. These files were randomly drawn from police agency records by staff who were provided with search parameters that included a call for police service that stemmed from a dispute, harassment, threat, or assault complaint or was flagged for IPV and that directly involved adults $(18+$ years $)$ in a current or former intimate partner relationship. The researchers reviewed these files to ensure that there was a clearly identifiable suspect and complainant role for the parties involved in the call. Failing this, a new file was requested. A total of 139 IPV incidents occurred in 2015, and three additional cases from 2014 were included because the ODARA for these cases was completed by police in 2015. Of these IPV incidents, $78 \%$ included a physical assault.

As shown in Table I, most suspects in the sample were male $(78.0 \%)$, and had a mean age of 35.7 years $(S D=13)$. Ethnicity information was not consistently recorded in police files, but for cases where this information was known $(n=98)$, most suspects were white/Caucasian $(85.7 \%)$. The majority of complainants were female $(77.3 \%)$, had a mean age of 33.4 years $(S D=13.85)$, and were also primarily white/ Caucasian (89.9\%) among the 89 cases where this was known. Most cases involved a current intimate partner relationship (74.3\%) among heterosexual couples (99.3\%).

\section{Measures}

\section{Police Records Coding Guide}

The research team adapted a coding guide previously developed under the Canadian observatory on the justice system response to IPV (Ursel et al., 2008). This guide was used to capture information about the index IPV event (e.g., date of incident, involved abusive behaviours, nature of injuries, presence of witnesses or children), suspect and victim characteristics (e.g., age, gender, employment status, history of IPV), relationship characteristics (e.g., duration of relationship, status of relationship as current vs. former), and police action to the index event in terms of legal actions taken (e.g., arrest and charge recommendation). Most variables were coded as Yes/Present, No/Absent, or unknown. In addition, two other measures were embedded in the coding guide to capture the severity of attempted violence and the severity of injury experienced by the victim in the course of the index event: the Level of Violence Scale and Level of Injury Scale (Messing, 2007).

\section{Level of Injury Scale (L-Injury)}

The degree of physical injury experienced by the victim of the IPV index event was captured using a scale developed by Messing (2007) from police records involving domestic violence situations. Severity of injury is rated by the evaluator across 5 different levels. Level 0 is scored when there are no injuries or complaints of pain/injury. Level 1 is scored when there are complaints of pain in the absence of visual injuries. Level 2 captures minor injuries such as marks, swelling, and 
TABLE I

Descriptive statistics for reviewed case files

\begin{tabular}{|c|c|c|}
\hline Variable & $\%$ & $M(S D)$ \\
\hline \multicolumn{3}{|l|}{ Suspect Characteristics } \\
\hline $\begin{array}{l}\text { Gender } \\
\text { Male } \\
\text { Female }\end{array}$ & $\begin{array}{l}78.0 \% \\
22.0 \%\end{array}$ & - \\
\hline Age & - & 35.66 years $(12.96)$ \\
\hline $\begin{array}{l}\text { Ethnicity } \\
\text { White/Caucasian } \\
\text { Minority }\end{array}$ & $\begin{array}{l}85.7 \% \\
14.3 \%\end{array}$ & - \\
\hline $\begin{array}{l}\text { Prior contact with police } \\
\text { No prior contact } \\
\text { Prior contact }\end{array}$ & $\begin{array}{l}61.3 \% \\
38.7 \%\end{array}$ & \\
\hline $\begin{array}{l}\text { Alcohol/drug use at index } \\
\text { Yes } \\
\text { No }\end{array}$ & $\begin{array}{l}39 \% \\
61 \%\end{array}$ & \\
\hline \multicolumn{3}{|l|}{ Victim Characteristics } \\
\hline $\begin{array}{l}\text { Gender } \\
\text { Male } \\
\text { Female }\end{array}$ & $\begin{array}{l}22.7 \% \\
77.3 \%\end{array}$ & - \\
\hline Age & - & 33.39 years $(13.90)$ \\
\hline $\begin{array}{l}\text { Ethnicity } \\
\text { White/Caucasian } \\
\text { Minority }\end{array}$ & $\begin{array}{l}89.9 \% \\
10.1 \%\end{array}$ & 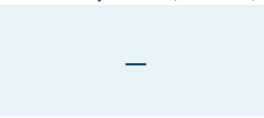 \\
\hline $\begin{array}{l}\text { Alcohol/drug use at index } \\
\text { Yes } \\
\text { No }\end{array}$ & $\begin{array}{l}21.3 \% \\
78.7 \%\end{array}$ & \\
\hline Relationship Characteristics & & - \\
\hline $\begin{array}{c}\text { Sexual orientation } \\
\text { Heterosexual } \\
\text { Homosexual }\end{array}$ & $\begin{array}{c}99.3 \% \\
0.7 \%\end{array}$ & \\
\hline $\begin{array}{l}\text { Relationship status } \\
\text { Current relationship } \\
\text { Prior relationship }\end{array}$ & $\begin{array}{l}74.3 \% \\
25.7 \%\end{array}$ & - \\
\hline $\begin{array}{l}\text { Relationship duration } \\
\text { more than } 1 \text { year } \\
\text { less than } 1 \text { year }\end{array}$ & $\begin{array}{l}77.5 \% \\
22.5 \%\end{array}$ & - \\
\hline $\begin{array}{l}\text { If separated, separation duration } \\
\text { less than } 1 \text { year } \\
\text { more than } 1 \text { year }\end{array}$ & $\begin{array}{l}88.2 \% \\
11.8 \%\end{array}$ & - \\
\hline $\begin{array}{l}\text { Children at home } \\
\text { Yes } \\
\text { No }\end{array}$ & $\begin{array}{l}63.8 \% \\
36.2 \%\end{array}$ & \\
\hline \multicolumn{3}{|l|}{ Index Event Details } \\
\hline $\begin{array}{l}\text { Physical violence } \\
\text { Yes } \\
\text { No }\end{array}$ & $\begin{array}{l}78.6 \% \\
21.4 \%\end{array}$ & \\
\hline L-Violence score & - & $2.58(1.32)$ \\
\hline L-Injury score & - & $1.09(1.28)$ \\
\hline $\begin{array}{l}\text { Arrested by police } \\
\text { Arrested } \\
\text { No arrest }\end{array}$ & $\begin{array}{l}52.5 \% \\
47.5 \%\end{array}$ & \\
\hline $\begin{array}{l}\text { Charge recommended by police to prosecutor } \\
\text { Charge recommended } \\
\text { No charge recommended }\end{array}$ & $\begin{array}{l}48.5 \% \\
51.5 \%\end{array}$ & \\
\hline $\begin{array}{l}\text { When recommended, did prosecutor approve charge }{ }^{b} \text { ? } \\
\text { Approved } \\
\text { Not approved }\end{array}$ & $\begin{array}{l}76.7 \% \\
23.3 \%\end{array}$ & \\
\hline
\end{tabular}

Note. "This variable is only relevant to 33 cases whose relationship status was "separated" at the time of the police call for service and for whom duration of separation was known. ${ }^{b}$ Cell values are based on the 60 cases for which police recommended a charge to the prosecutor following arrest of the suspect. 
scratches, while moderate injuries resulting in bruising, black eye, cuts, or a bloody nose are scored as Level 3 injuries. Severe injuries are scored as Level 4 and include broken bones, missing/broken teeth, loss of consciousness, and severe cuts requiring stitches or more serious interventions. Hospitalization and death would also be scored as Level 4 for the purposes of the current study, though not specifically noted in Messing's scheme. Prior research has found high inter-rater reliability for scoring the L-Injury scale, and higher injury scores were related to higher ODARA risk scores in cases where physical injury had occurred (Moser, 2012).

\section{Level of Violence Scale (L-Violence)}

Given that a perpetrator may use physical violence on a scale of severity that may or may not correspond to the injury this violence inflicts (e.g., tried to hit the victim, but missed), Messing developed a second scale to capture attempted violence independent of the actual injury. This scale is used to appraise the severity of physical violence used by the perpetrator at the index offense based on 5 levels of increasing severity. Level 0 is scored when there was no physical violence enacted or attempted. Level 1 is scored when indirect forms of physical violence occurred, such as vandalism and forcible entry. Level 2 is scored for minor acts of violence that may include such acts as throwing objects, punching and slapping, and Level 3 captures moderate acts of violence, including strangulation, kicking, grabbing, and slamming. Finally, severe violence is scored as Level 4 and includes enacted or attempted acts, such as punching and biting. We also added other serious violent acts not captured by Messing's scale, including shooting/ attempting to shoot and stabbing/attempting to stab. Past research has demonstrated high inter-rater reliability for this scale, as well as identified positive correlations between the L-Violence scores and ODARA risk scores when some form of physical violence was present at the index event (Moser, 2012).

\section{Ontario Domestic Assault Risk Assessment (ODARA)}

The ODARA (Hilton et al., 2004; Hilton et al., 2010) contains 13 items that are rated by the assessor based on information normally available to police, either through a search of police databases or interviews with the involved parties and witnesses. These items tap into criminal history, behaviour during IPV (e.g., assault on victim when pregnant), characteristics of the index offense (e.g., confinement of partner, threats to harm or kill), information pertaining to the relationship context (e.g., victim has children from previous relationship), as well as the victim's circumstances (e.g., existing barriers to support) and signs of substance abuse. These items are rated as either Yes, present (scored a 1) or No, absent (scored a 0 ). The ratings across items are then summed to generate a total risk score. Based on statistical analyses by the test developers, cut points have been established for the total score to aid interpretation for risk appraisal. Specifically, scores of 0 to 3 are interpreted as representing a low risk of subsequent IPV, scores of 4 to 6 represent moderate risk, and scores of 7 or higher reflect a high-risk individual.

Based on file-coded scorings of the ODARA by researchers, the ability of the ODARA has adequate inter-rater reliability (Hilton et al., 2008) and can reliably predict subsequent IPV among male perpetrators at least to a moderate degree based on Receiving Operator Characteristics Curve analyses (Hilton
\& Harris, 2009; Jung \& Buro, 2017). The ODARA produced the strongest predictive validity estimates among intimate partner risk measures in a meta-analysis by Messing and Thaller (2013). Validity data with the ODARA is more limited with female perpetrators of IPV, most of which has relied on very small samples $(n \leq 30)$, with mixed results. Both Hilton et al. (2014) and Moser (2012) found that the ODARA produced moderate to large effect sizes for predicting subsequent IPV, though the actual rates of reoffending across risk levels were different from those generated with males. However, McTague (2018) recently found that the ODARA was an unreliable estimator of subsequent IPV for female perpetrators in a larger sample of 99 women who came into contact with police for IPV perpetration. Given the limited validity data available for females, the New Brunswick Government's Department of Public Safety did not recommend the use of the ODARA for women (or youth) in their guidelines for use by police agencies. However, females were included in the current study to assess practices of use among the partnering police agencies with this sub-group. As noted, there is no data on the validity of the ODARA when scored by police in real-time in the field.

\section{Procedure}

The three policing agencies involved in the current study were invited to partner on a research project aimed at understanding the influence of the ODARA on police response to IPV and to inform the development of a police-community strategy for IPV. The three agencies agreed to participate in the study and facilitated access to their case records for examination by the researchers after the researchers and our graduate-level research assistants received appropriate security clearances and Research Ethics Board approval from the University of New Brunswick (omitted for blind review) for secondary use of the information. The three police agencies provided records from cases that included both urban and rural catchment areas. Although each of these organizations adopted use of the ODARA by their frontline officers, they varied in their context and policy application regarding IPV-related services and implementation of the ODARA. Specifically, Organization C had a Domestic Violence Court operating within its jurisdiction, whereas the other two organizations operated within a traditional criminal and family court context. Organization B was unique in that it had a dedicated family violence coordinator who was tasked with ensuring compliance with domestic violence abuse protocols established by the province and completion of the risk assessment tool. Organization A adopted the provincial policy for use of the ODARA, but expanded its use to females. They had no dedicated domestic violence coordinator at the time of data collection but worked in collaboration with victim services in an informal capacity in this regard. These variations in policy, context, and procedure created a unique opportunity to examine the influence of organization variations on the use of the ODARA in the current study.

Designated policing staff from three organizations randomly pulled a total of 150 files initially (target of 50 files per organization), but eight cases were excluded due to excessive missing information. These files were all concluded cases with known legal outcomes (e.g., cleared by no charge, cleared by charge or conviction). All files were taken from 
2015, after officers had received IPV and ODARA training. The researchers on-site at the respective police organization reviewed police records. These files varied in the quality and quantity of information contained within them across organizations but typically included police officer narratives describing the index event, victim and suspect demographic details and statements, and sometimes criminal record sheets and prosecutor information in terms of approved charges, convictions, and sentences stemming from the index event if the matter had proceeded to court. If the ODARA had been completed, this was noted and the police-scored items and total score were recorded. Findings pertaining to this latter aspect of the larger study were not included in the current study as the focus was solely on whether officers used the ODARA.

Two graduate students and two of the authors assumed primary responsibility for coding files. Training on the coding process was provided through discussion, practice coding, and review of coding decisions until consensus was reached. Then inter-rater reliability was formally assessed on $20 \%$ of the cases drawn from various points in the data coding process to minimize coder drift. Inter-rater reliability of the coding guide was assessed by Kappa for categorical variables and Inter-class correlation coefficients (two-way, random model) for continuous variables. Only variables with inter-relater reliability values (Kappa and ICC) > .60 were used for the analysis.

\section{RESULTS}

\section{Administration of the ODARA}

The ODARA was administered by police in $60.3 \%$ of the reviewed cases of IPV. Despite randomly pulling files from of the three police organizations, there was significant variation in ODARA administration rates across them, $\chi^{2}(2)=$ $31.67, p<.001$, Cramer's $V=.48$. Specifically, Organization C infrequently administered the ODARA (32.0\%) relative to Organization B (90.0\%) and Organization A (64.0\%). Administration of the ODARA was not dependent on the reporter of the incident to police (victim, $\chi^{2}(2)=.00, p=.99$, Cramer's $V$ $=.002$; suspect, $\chi^{2}(2)=00, p=1.00$, Cramer's $V=.00$; child, $\chi^{2}$ $(2)=2.10, p=.15$, Cramer's $V=.12$; other relative, $\chi^{2}(2)=2.74$, $p=.10$, Cramer's $V=.14$; neighbours $/$ friends, $\chi^{2}(2)=.60, p=$ .44 , Cramer's $V=.06)$. Thus, there did not appear to be apparent bias in ODARA use as a function of the reporting party.

Table II contains additional comparisons across suspect, victim, relationship context, index event details, and legal responses for cases in which the ODARA was administered when responding to an IPV incident relative to when it was not. As described in the table, the ODARA was more likely to be administered when the suspect was using drugs/alcohol $(76.4 \%)$, was employed $(79.4 \%)$, and was on probation/ community supervision $(80.0 \%)$. No victim factors were associated with ODARA use; however, the ODARA was more likely to be used when the incident was between parties in a current intimate relationship $(67.0 \%)$, when physical violence occurred in the index event $(70.6 \%)$, and when a weapon was used $(84.2 \%)$. It should be noted that officers did not administer the ODARA in $29.4 \%$ of IPV calls that involved physical violence where risk appraisal was likely warranted by policy. Overall, Table II results indicate no evidence of apparent demographic characteristic biases in the choice to use the ODARA, given the absence of significant variations across suspect or victim age, gender, and ethnic status. The duration of the current relationship or the duration of separation, broadly defined in the current study, were also similar across ODARA and non-ODARA use files.

To better understand ODARA use as a function of index event severity and Organization nuances, a multivariate analysis of variance (MANOVA) was conducted with ODARA use (yes/no) and Organization type (A, B, C) entered as independent variables and the L-Violence and L-Injury scores as dependent measures. The omnibus model produced a significant main effect for the completion of the ODARA on these severity measures, Pillai's Trace $=.11, F(2,131)=8.45, p<$ .001, $\eta_{p}{ }^{2}=.11$, but no significant main effect of organization on severity measures, Pillai's Trace $=.05, F(4,264)=1.81, p=$ $.12, \eta_{p}^{2}=.04$. However, a significant interaction between Organization and ODARA administration was observed across severity measures, Pillai's Trace $=.12, F(4,264)=4.37, p=.002$, $\eta_{p}{ }^{2}=.11$. Follow-up univariate analyses of variance indicated that this interaction was significant for both the L-Injury and L-Violence scales, $F(2,132)=8.78, p<.001, \eta_{p}{ }^{2}=.12$ and $F(2$, $132)=3.47, p=.03, \eta_{p}^{2}=.05$, respectively. As shown in Figure 1 , administration of the ODARA was unrelated to the severity of attempted violence during the index event in Organization A given its overlapping standard error bars. However, interpretation of the standard error bars for Organization C indicate that ODARA administration in that organization was more likely in cases with higher mean L-Violence scores than lower forms of violence. Use of the ODARA for Organization B was also associated with a higher mean score on the L-Violence score, but its standard error bars overlapped with L-Violence scores for cases where the ODARA was not used. Figure 2 depicts a similar interaction pattern for the L-Injury scale.

\section{ODARA Administration and Legal Responses}

In terms of legal responses (see Table II), when the ODARA was administered, the officer was more likely to arrest the suspect $(70.2 \%)$ than when they did not use it (26.8\%). Beyond simple administration, higher total ODARA scores generated by the officers predicted suspect arrest, Area Under the Curve $=.78$ [95\% CI .67,.89], representing a large effect size for this outcome. Once arrested, officers recommend charges to the prosecutor for most cases, but this was more likely when the ODARA was used $(100 \%)$ relative to when it was not (71.4\%). However, ODARA administration had no significant influence on whether the prosecutor approved the charge; that said, prosecutor charge approval post-arrest was high regardless of whether the ODARA was administered (72\% when used/100\% when not used).

\section{DISCUSSION}

Our study presents several important findings concerning the use of the ODARA in the field by police officers. First, the ODARA was used with most IPV cases, yet several factors impacted when it was more likely to be used. Police officers generally followed protocol that outlines how to determine which cases necessitate the use of ODARA. However, there was site variation in the frequency with which the ODARA was used. Organization C used the ODARA 
Comparison of case parameters as a function of ODARA administration

\begin{tabular}{|c|c|c|c|c|}
\hline Variable & $\begin{array}{l}\text { ODARA Used } \\
\% / M(S D)\end{array}$ & $\begin{array}{c}\text { No ODARA Used } \\
\% / M(S D)\end{array}$ & $\begin{array}{l}\chi^{2} \text { or } \\
\text { F-Statistic }\end{array}$ & $\begin{array}{c}\text { Cramer's V } \\
\text { or } \eta_{p}^{2}\end{array}$ \\
\hline \multicolumn{5}{|l|}{ Suspect Characteristics } \\
\hline $\begin{array}{l}\text { Gender } \\
\text { Male } \\
\text { Female }\end{array}$ & $\begin{array}{l}56.9 \% \\
71.0 \%\end{array}$ & $\begin{array}{l}43.1 \% \\
29.0 \%\end{array}$ & 2.00 & .12 \\
\hline Age (years) & $35.37(13.26)$ & $35.80(12.54)$ & .04 & .00 \\
\hline $\begin{array}{l}\text { Ethnicity } \\
\text { White } \\
\text { Minority }\end{array}$ & $\begin{array}{l}85.7 \% \\
73.5 \%\end{array}$ & $\begin{array}{l}26.5 \% \\
14.3 \%\end{array}$ & .96 & .33 \\
\hline $\begin{array}{l}\text { Employed } \\
\text { Yes } \\
\text { No }\end{array}$ & $\begin{array}{l}79.4 \% \\
44.4 \%\end{array}$ & $\begin{array}{l}20.6 \% \\
55.6 \%\end{array}$ & $6.54^{*}$ & .35 \\
\hline $\begin{array}{l}\text { Prior contact with police } \\
\text { Yes } \\
\text { No }\end{array}$ & $\begin{array}{l}75.5 \% \\
53.0 \%\end{array}$ & $\begin{array}{l}24.5 \% \\
47.0 \%\end{array}$ & $6.91^{* *}$ & .22 \\
\hline $\begin{array}{l}\text { On Probation } \\
\text { Yes } \\
\text { No }\end{array}$ & $\begin{array}{l}80.0 \% \\
55.7 \%\end{array}$ & $\begin{array}{l}20.0 \% \\
44.4 \%\end{array}$ & $5.07^{\star}$ & .19 \\
\hline $\begin{array}{l}\text { Alcohol/drug use at index } \\
\text { Yes } \\
\text { No }\end{array}$ & $\begin{array}{l}76.4 \% \\
49.4 \%\end{array}$ & $\begin{array}{l}23.6 \% \\
50.0 \%\end{array}$ & $10.11^{* * *}$ & .27 \\
\hline \multicolumn{5}{|l|}{ Victim Characteristics } \\
\hline $\begin{array}{l}\text { Gender } \\
\text { Male } \\
\text { Female }\end{array}$ & $\begin{array}{l}68.8 \% \\
57.4 \%\end{array}$ & $\begin{array}{l}31.3 \% \\
42.6 \%\end{array}$ & 1.32 & .10 \\
\hline $\begin{array}{l}\text { Ethnicity } \\
\text { White } \\
\text { Minority }\end{array}$ & $\begin{array}{l}74.7 \% \\
88.9 \%\end{array}$ & $\begin{array}{c}25.3 \% \\
11.1 \%\end{array}$ & .90 & .10 \\
\hline $\begin{array}{l}\text { Pregnant (females) } \\
\text { Yes } \\
\text { No }\end{array}$ & $\begin{array}{l}100 \% \\
58.5 \%\end{array}$ & $\begin{array}{c}0 \% \\
41.5 \%\end{array}$ & 3.46 & .16 \\
\hline $\begin{array}{l}\text { Employed } \\
\text { Yes } \\
\text { No }\end{array}$ & $\begin{array}{l}73.5 \% \\
69.2 \%\end{array}$ & $\begin{array}{l}25.5 \% \\
30.8 \%\end{array}$ & .09 & .04 \\
\hline $\begin{array}{l}\text { On probation } \\
\text { Yes } \\
\text { No }\end{array}$ & $\begin{array}{l}75.0 \% \\
59.6 \%\end{array}$ & $\begin{array}{l}25.0 \% \\
40.4 \%\end{array}$ & .39 & .05 \\
\hline $\begin{array}{l}\text { Alcohol/drug use at index } \\
\text { Yes } \\
\text { No }\end{array}$ & $\begin{array}{l}73.3 \% \\
55.4 \%\end{array}$ & $\begin{array}{l}26.7 \% \\
43.6 \%\end{array}$ & 2.83 & .14 \\
\hline \multicolumn{5}{|l|}{ Relationship Characteristics } \\
\hline $\begin{array}{l}\text { Relationship status } \\
\text { Current } \\
\text { Prior }\end{array}$ & $\begin{array}{l}67.0 \% \\
38.9 \%\end{array}$ & $\begin{array}{l}33.0 \% \\
61.1 \%\end{array}$ & $8.76^{* *}$ & .25 \\
\hline $\begin{array}{l}\text { Relationship duration } \\
\text { more than } 1 \text { year } \\
\text { less than } 1 \text { year }\end{array}$ & $\begin{array}{l}75.0 \% \\
51.5 \%\end{array}$ & $\begin{array}{l}25.0 \% \\
48.5 \%\end{array}$ & 3.49 & .20 \\
\hline $\begin{array}{l}\text { Children at home } \\
\text { Yes } \\
\text { No }\end{array}$ & $\begin{array}{l}61.7 \% \\
60.0 \%\end{array}$ & $\begin{array}{l}38.3 \% \\
40.0 \%\end{array}$ & .04 & .02 \\
\hline $\begin{array}{l}\text { Jealousy of suspect towards victim } \\
\text { Yes } \\
\text { No }\end{array}$ & $\begin{array}{l}75.0 \% \\
58.8 \%\end{array}$ & $\begin{array}{l}25.0 \% \\
41.4 \%\end{array}$ & 1.23 & .09 \\
\hline \multicolumn{5}{|l|}{ Index Event Details } \\
\hline $\begin{array}{l}\text { Physical violence } \\
\text { Yes } \\
\text { No }\end{array}$ & $\begin{array}{l}70.6 \% \\
23.3 \%\end{array}$ & $\begin{array}{l}29.4 \% \\
76.7 \%\end{array}$ & $22.02 * * *$ & .40 \\
\hline
\end{tabular}


TABLE II Continued

\begin{tabular}{|c|c|c|c|c|}
\hline Variable & $\begin{array}{l}\text { ODARA Used } \\
\% / M(S D)\end{array}$ & $\begin{array}{c}\text { No ODARA Used } \\
\% / M(S D)\end{array}$ & $\begin{array}{l}\chi^{2} \text { or } \\
\text { F-Statistic }\end{array}$ & $\begin{array}{c}\text { Cramer's V } \\
\text { or } \mathrm{y}_{p}^{2}\end{array}$ \\
\hline \multicolumn{5}{|l|}{ Index Event Details Continued } \\
\hline $\begin{array}{l}\text { Weapon use }{ }^{ \pm} \\
\text {Yes } \\
\text { No }\end{array}$ & $\begin{array}{l}84.2 \% \\
56.2 \%\end{array}$ & $\begin{array}{l}15.8 \% \\
43.8 \%\end{array}$ & $5.37^{*}$ & .20 \\
\hline L-Violence score & $3.04(1.03)$ & $1.91(1.44)$ & $28.65^{* * *}$ & .17 \\
\hline L-Injury score & 1.39 (1.31) & $0.66(1.12)$ & $11.80 * * *$ & .08 \\
\hline \multicolumn{5}{|l|}{ Legal Responses } \\
\hline $\begin{array}{l}\text { Arrested by police } \\
\text { Yes } \\
\text { No }\end{array}$ & $\begin{array}{l}70.2 \% \\
29.8 \%\end{array}$ & $\begin{array}{l}26.8 \% \\
73.2 \%\end{array}$ & $25.46^{* * *}$ & .43 \\
\hline $\begin{array}{l}\text { If arrested, was charge recommended by police? } \\
\text { Yes } \\
\text { No }\end{array}$ & $\begin{array}{l}100 \% \\
0 \%\end{array}$ & $\begin{array}{l}71.4 \% \\
28.6 \%\end{array}$ & $16.68^{* * *}$ & .49 \\
\hline $\begin{array}{l}\text { If recommended, did prosecutor approve charge? } \\
\text { Yes } \\
\text { No }\end{array}$ & $\begin{array}{l}72.0 \% \\
28.0 \%\end{array}$ & $\begin{array}{c}100 \% \\
0 \%\end{array}$ & 3.65 & .25 \\
\hline
\end{tabular}

Note. With the exception of legal responses variables, all cross-tab comparisons percentage values are reported from within the perspective of the descriptor variable status. Cross-tab comparisons percentages for legal response variables are reported from within the perspective of ODARA use status. ${ }^{ \pm}$Fisher's Exact Test was used for statistical significance given small cell size in this variable. ${ }^{b}$ Cell values are based on the 60 cases for which police recommended a charge to the prosecutor following arrest of the suspect.

${ }^{*} p \leq .05 .{ }^{* *} p \leq .01 .{ }^{* *} p \leq .001$

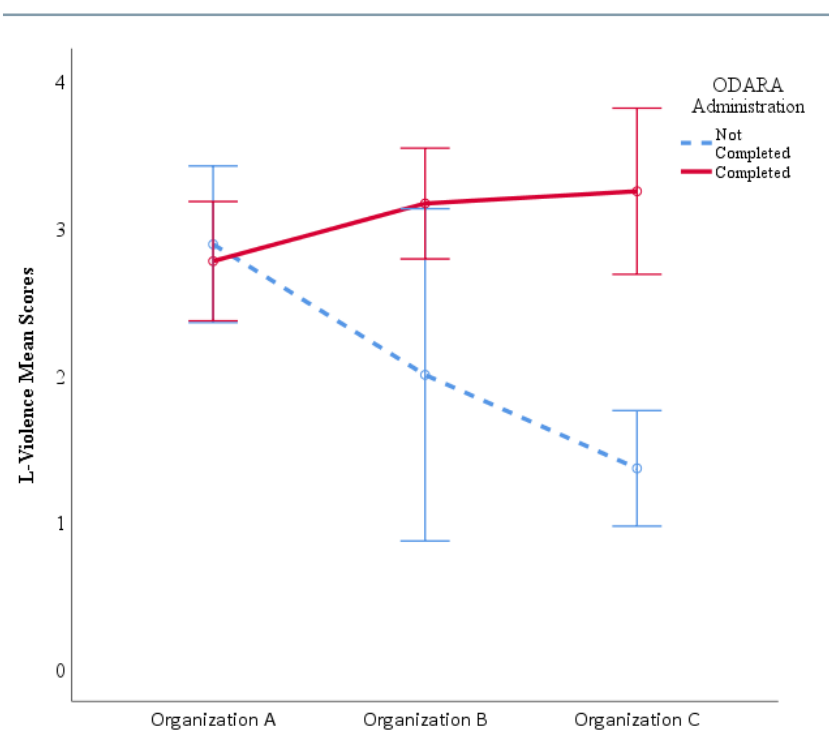

FIGURE 1 Interaction effect of ODARA Administration status and Police Organization for L-Violence scores from the index event. Bars represent $+/-2$ standard errors.

rather infrequently ( 1/3 of files), whereas organization $B$ used it for most of their cases. ( $90 \%$ of files). Organization A fell in between, using it more often than not for its IPV cases (64\% of files). Demonstrating the impact of police perceptions of IPV (See Ballucci et al., 2017; Gill et al., 2019), police were most likely to respond with action in cases were the severity of the injuries is physically obvious, and when the incident was between parties in a current, rather than previous, intimate relationship (67.0\%). Although the cases drawn from each organization were not notably different

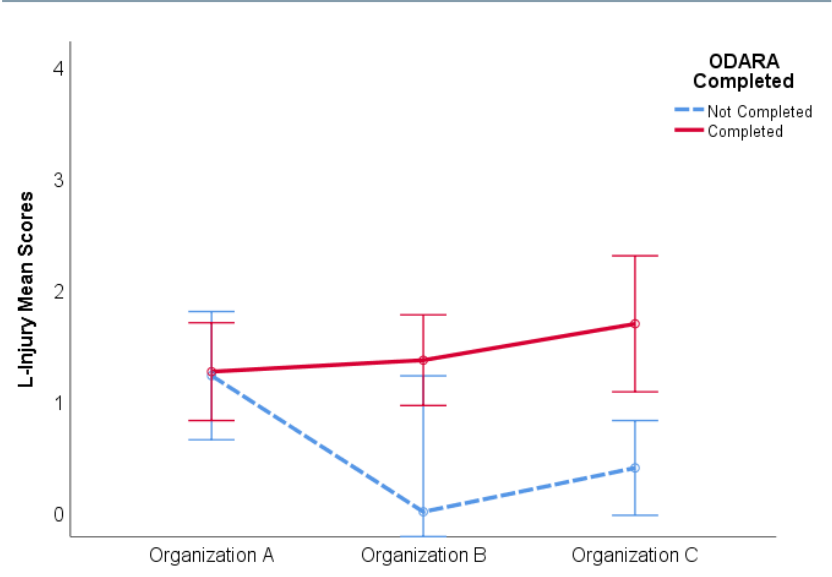

FIGURE 2 Interaction effect of ODARA Administration status and Police Organization for L-Injury scores from the index event. Bars represent +/- 2 standard errors.

in the severity of violence or injury, there was a significant interaction with ODARA.

Other than the violence and injury factors, the suspect and victim gender, age, ethnicity, and their relationship status did not predict ODARA use. This finding may be the influence of domestic violence training that challenges these biases. Other than organization site, the only other variable that significantly contributed to ODARA use was the suspect's alcohol or drug use. Paradoxically, however, when a suspect was abusing substances in relation to the index event, officers were less likely to use the ODARA. This finding goes against knowledge of substance abuse as a risk factor for IPV (Easton et al., 2007). The officers' decision to dismiss the risk involved when substance is in use, and not complete the ODARA, can 
result in police responses that do not recognize, and therefore address, the potential danger to the victim/survivor. This example suggests that police officers are using their subjective perceptions of risk to determine their response rather than using the tool as intended to guide this response. This practice may be a product of police officers' negative attitudes towards risk assessment tools, which further supports the need for policy that mandates their use and oversight in the use of these tools in the field.

Second, the ODARA total score was predictive of the decision to arrest in the current study. Police officers' use of the ODARA and decision to arrest increased significantly in cases where the ODARA score was higher, the suspect was male, and the level and severity of attempted violence and injury to the complainant were physically evident. Organization $C$ tended to reserve their use of the ODARA for only those cases that included a high level of attempted violence, which resulted in a higher degree of complainant injury. However, when an individual call for service does not involve physical injury, police officers may have fewer legal grounds to make an arrest or feel less confident in the likelihood of prosecution of the case in the absence of tangible evidence. These findings suggest that ODARA scores are useful tools to support charges and convictions in courts, but only if they are used. Police officers may use the ODARA when deciding grounds for arrest and, in the use of arrest, as a risk mitigation strategy as it allows them to detain the suspect.

The differences in police usage of the ODARA may be attributed to the variation in infrastructure that exists to respond to and support officers dealing with IPV-specific cases. For instance, Organization $C$ has a domestic violence court, which may shape police officers' perceptions of IPV and may impact their decision to complete a risk assessment (for example, they may assume it would be completed in preparation for court). Organization B had a domestic violence coordinator who reviewed IPV cases to ensure adherence to protocols for risk assessment. The greater use of the ODARA at Organization B may be attributed to the oversight and follow-up provided by a dedicated domestic violence coordinator in the organization. Organization A continued to use the ODARA most of the time as per policy.

Although the ODARA is frequently used, there remains evidence that cases that should have been evaluated using the ODARA were not. In only $40 \%$ of the cases identified as meeting the province's definition of IPV was the ODARA risk appraisal documented in case records. The province of New Brunswick defines IPV as having:

many forms: physical, verbal, emotional, psychological, sexual, financial, spiritual. IPV is based on a relationship of domination. Victims may suffer from isolation, harassment, humiliation, intimidation, threats, physical and sexual violence, and emotional blackmail. The abusive partner may also abuse the victim by controlling the victim's income and expenses in order to take away independence. The partner's hold over the victim might extend to a psychological level. (Government of New Brunswick, 2020)

Police officers are made aware of this definition in their training. However, the ODARA assessment tool is designed to be used only in situations where there is evidence of physical violence or the threat of such violence, as suggested below in work describing the development of the ODARA:

In order for a case to qualify, we identified as an index incident the most recent domestic incident known to police in which the man engaged in domestic violence against a female domestic partner. We had to be confident that the man engaged in at least one physical act of violence, so we required evidence in the police report of physical contact with the victim or a credible threat of death with a weapon in hand in the presence of the victim. (Mental Health Centre Penetanguishene, 2005, 11)

This directive for ODARA use versus training on the broader definitions of IPV can create ambiguity and inconsistency concerning when the assessment tool can and should be used. As a result, victims/survivors in these cases are vulnerable to ineffective and insufficient police action that could then increases the potential for future violence. A likely explanation for this practice, given that no mandatory legislation in this jurisdiction requires police officers to complete an ODARA, is that police officers are exercising their discretion even when the criteria for risk assessment are present. Despite the province-wide implementation of a definition of IPV, training in the dynamics of IPV, province-wide adoption of a risk assessment tool by the policing leadership, and provincially defined policy standards for when to use the ODARA, police officers and their organizations maintain the discretionary power to choose the conditions under which they complete the ODARA and whether they complete it at all.

The literature shows that a police officer's decision not to complete a risk assessment may be a result of limited training (Gover et al., 2011; DeJong et al., 2008; Tatum \& Pence, 2015; Poon et al., 2014). However, this is only part of the explanation. Police officers are also reluctant to use risk assessment tools because they view them as a replacement for their experience and as limiting their discretionary power (Ballucci et al., 2017). This perception is, in part, a reflection of how risk assessment tools, such as the ODARA, are integrated into policing and presented to police officers. Their utility must be introduced as a source of information to shape police officers' discretionary assessments. To improve the use and utility of the ODARA, what is necessary is not only training on how to complete the tool, but rather a general understanding of how the tool can inform police officers in their decisions. A more comprehensive approach to integrating the ODARA, one that goes beyond adding a step to the policing process, creates the potential for a more expansive and appropriate use of what the ODARA offers.

\section{CONCLUSION}

Currently, there remains a disconnection between when to use the ODARA and how to complete the scoring which can lead officers to see the completion of this tool as an administrative task, only to be used when evidence of physical violence is present, rather than an information source to guide police response. A lack of understanding concerning the complexity of IPV (Gill et al., 2019), and the utility of the 
ODARA directly impacts victim/survivors. For example, limited knowledge of the complexity of IPV (which can be learned through ODARA training) can, for example, result in police officers responding only to a single incident call for service, rather than viewing this call within a broader context of case history known to the police. The index call may be for a non-physical incident, while there is a known history of prior physical assaults by the perpetrator against this same or other intimate partners. If police officers do not consider the broader pattern of behaviour, an officer may view the index event as minor and determine that no risk appraisal is relevant to inform a response to this particular call.

Overall, our study shows that the ODARA, as all risk assessment tools, informs better-quality discretionary decision-making, if presented and integrated with proper training on tool use that includes education on how the assessment tool can inform police officers' understanding of risk and better inform their responses to maximize risk mitigation. The lack of compliance with policies for the ODARA's use increases opportunities for misapplied discretion when responding to IPV calls. Our findings further emphasize the need to both increase awareness of the risk factors for IPV and dynamics of abuse, and motivate police officers to increase their use of structured risk appraisal tools to inform discretionary judgments.

The policy implications of our study include not only increased police training but also, more specifically, comprehensive training that emphasizes the objectives of ODARA and how it helps identify the complexity of IPV incidents. Along with stronger policies that mandate the use of the ODARA, we recommend increasing officers' understanding of situations so that they are better able to combine their experience with policy and knowledge. Although standardized tools are often heralded as an effective way to better police practices, without proper training on both their use and objectives, their effectiveness is minimized. The potential of the ODARA is great. The knowledge gained from the ODARA can help reduce the incidence of IPV. Officers' discretionary power, in conjunction with their knowledge of IPV risk factors, has the potential to inform officers with alternative ways to respond to IPV calls to mitigate risk in high-risk, non-injury calls for service (e.g., harassment, break and enter, property damage). The ODARA, therefore, can be used as a preventive and proactive measure; it helps increase police officers' abilities to identify the potential for escalation and respond in ways to reduce future harm for victims.

\section{Limitations and Future Research}

Although we identify the frequency of ODARA use and some of the factors associated with this use by police officers, there are limitations to our findings. First, we did not have individual information on the police officers who completed the ODARA, such as their attitudes towards IPV and risk assessment tools, which, as we have shown in previous work, impacts police response to IPV (Ballucci et al., 2017). Second, there were limitations to our data access that may explain the variation in characteristics that determine the use of risk assessment tools within each of our organizations. Third, the information available concerning the details of the index IPV call were limited to only those recorded in the file, which may lack important details that influence police officer decision-making regarding the ODARA. There is, for example, the possibility that Organization $C$ completed the ODARA more often but did not include the assessment in the paper records that we were provided for review, despite our asking for the complete file. Finally, our study does not examine whether the use of the ODARA positively influenced police response to mitigate subsequent IPV when it was used to inform decision-making.

Several future research projects can be recommended based on our study. Examining whether police officers complete the ODARA only provides partial information for policy recommendations. It is necessary to examine what actions the ODARA risk appraisal leads to and whether those actions by police assist with reducing future incidents. Further studies are also needed to better understand when and how police use risk appraisal information to inform their decision-making and actions in IPV cases (see Spivak et al., 2020). For example, anecdotal information indicates that instead of completing the risk assessment tools immediately after the call, police officers complete risk assessments tools once they return to their station, days after the call or in some cases only if an arrest is made, or expected (i.e., completed as a formality to meet policy expectations, but not to inform decision-making as intended). The timing of completion is imperative for effective risk mitigation, including prompt action for safety planning. Lastly, our results show that despite meeting the IPV definition, the ODARA was not completed in $29.4 \%$ of cases. The percentage of police officers who did not use the ODARA as expected by policy suggests the need for further studies-in other Canadian provinces and abroad-to better understand police use of risk instruments and appraisal processes when responding to IPV calls for service.

\section{ACKNOWLEDGEMENTS}

This research was supported by an Insight Development Grant \#430-2013-001034 from the Social Sciences and Humanities Research Council of Canada (SSHRC). We would also like to thank our partnering police organizations for their collaboration on this project.

\section{CONFLICT OF INTEREST DISCLOSURES}

The authors declare that there are no conflicts of interest

\section{AUTHOR AFFILIATIONS}

*Department of Sociology, University of Western Ontario, London, ON; ' Department of Psychology, University of New Brunswick, Saint John, NB; ‘Department of Sociology, University of New Brunswick, Fredericton, NB.

\section{REFERENCES}

Ariza, J., Robinson, A., \& Myhill, A. (2016). Cheaper, faster, better: Expectations and achievements in police risk assessment of domestic abuse. Policing, 10(4), 341-350. doi: 10.1093/police/paw023

Ballucci, D., Gill, C., \& Campbell, M. A. (2017). The power of attitude: The role of police culture and receptivity of risk assessment tools in IPV calls. Policing: A Journal of Policy and Practice, 17 (3), 242-257. doi: 10.1093/police/pax018

Belfrage, H., Strand, S., Storey, J., Gibas, A., Kropp, R., \& Hart, S. (2012). Assessment and management of risk for intimate partner violence by police officers using the spousal assault risk assessment guide. Law and Human Behavior, 36(1), 60-67. doi: 10.1037/h0093948

Bonta, J., \& Andrews, D. (2017). The psychology of criminal conduct (Sixth edition.). Routledge, Taylor \& Francis Group. 
Bowen, E. (2011). An overview of partner violence risk assessment and the potential role of female victim risk appraisals. Aggression and Violent Behavior, 16(3), 214-226. doi: 10.1016/i.avb.2011.02.007

Campbell, M. A., Gill, C., \& Ballucci, D. (2018). Informing police response to intimate partner violence: Predictors of perceived usefulness of risk assessment screening. Journal of Police and Criminal Psychology, 33(2), 175-187. doi: 10.1007/s1 1896-017-9244-y

Canales, D., Macaulay, A. McDougall, A., Wei, R., Campbell, M.A. (2013). A brief synopsis of risk assessment screening tools for frontline professionals responding to intimate partner violence. Centre for Criminal Justice Studies. University of New Brunswick. https://www. unb.ca/saintjohn/ccjs/_resources/pdf/ipvrisktoolsynopsis2013.pdf

Chappell, A. T., Maggard, S. R., \& Higgins, J. L. (2013). Exceptions to the rule? Exploring the use of overrides in detention risk assessment. Youth Violence and Juvenile Justice, 17(4), 332-348. doi: $10.1177 / 1541204012470849$

Dawson, M., \& Hotton, T. (2014). Police charging practices for incidents of intimate partner violence in Canada. Journal of Research in Crime and Delinquency, 51(5), 655-683. doi: 10.1177/0022427814523787

Dejong, C., Burgess-Proctor, A., \& Elis, L. (2008). Police officer perceptions of intimate partner violence: An analysis of observational data. Violence and Victims, 23(6), 683-696. doi: 10.1891/0886-6708.23.6.683

Department of Justice Canada. (2014). Making the links in family violence cases: Collaboration among the family, child protection, and criminal justice systems. Department of Justice Canada. https://www.justice. gc.ca/eng/rp-pr/ci-jp/fv-vf/mlfvc-elcvf/vol2/mlfvc2-elcvf2.pdf

Durfee, A., \& Fetzer, M. D. (2016). Offense type and the arrest decision in cases of intimate partner violence. Crime \& Delinquency, 62 (7), 954-977. doi: 10.1177/0011128714540277

Easton, C., Mandel, D., Babuscio, T., Rounsaville, B. J., \& Carroll, K. M. (2007). Differences in treatment outcome between male alcohol dependent offenders of domestic violence with and without positive drug screens. Addictive Behaviors, 32(10), 2151-2163. doi: 10.1016/i.addbeh.2007.01.031

Gill, C., Campbell, M. A., \& Ballucci, D. (2019). Police officers' definitions and understandings of intimate partner violence in New Brunswick, Canada. The Police Journal: Theory, Practice and Principles. doi: $10.1177 / 0032258 \times 19876974$

Gover, A. R., Paul, D. P., \& Dodge, M. (2011). Law enforcement officers' attitudes about domestic violence. Violence Against Women, 1715), 619-636. doi: 10.1177/1077801211407477

Government of New Brunswick (2020). What is intimate partner violence? Public Safety: https://www2.gnb.ca/content/gnb/en/ departments/public-safety/community_safety/content/intimate_ partner_violence/i_want_to_understand/what_is.html, retrieved May 29, 2020

Gracia, E., García, F., \& Lila, M. (2014). Male police officers' law enforcement preferences in cases of intimate partner violence versus non-intimate interpersonal violence: Do sexist attitudes and empathy matter? Criminal Justice and Behavior, 41(10), 1195-1213. doi: $10.1177 / 0093854814541655$

Guay, J-P., \& Parent, G. (2018). Broken legs, clinical overrides, and recidivism risk. An analysis of decisions to adjust risk levels with the LS/CMI. Criminal Justice and Behavior, 45(1), 82-100. doi: $10.1177 / 0093854817719482$

Hilton, N. Z., \& Harris, G. T. (2009). How nonrecidivism affects predictive accuracy: Evidence from a cross-validation of the Ontario Domestic Assault Risk Assessment (ODARA). Journal of Interpersonal Violence, 24(2), 326-337. doi: 10.1177/0886260508316478

Hilton, N. Z., Harris, G. T., \& Holder, N. (2008). Actuarial assessment of violence risk in hospital-based partner assault clinics. Canadian Journal of Nursing Research, 40(4), 56-70.
Hilton, N. Z., Harris, G. T., Rice, M. E. (2010). Risk assessment for domestically violent men: tools for criminal justice, offender intervention, and victim services (1st ed.). American Psychological Association.

Hilton, N. Z., Harris, G. T., Rice, M. E., Lang, C., Cormier, C. A., \& Lines, K. J. (2004). A Brie actuarial assessment for the prediction of wife assault recidivism: The Ontario Domestic Assault Risk Assessment. Psychological Assessment, 16(3), 267-275. doi: 10.1037/10403590.16.3.267

Hilton, N., Popham, S., Lang, C., \& Harris, G. (2014). Preliminary validation of the ODARA for female intimate partner violence offenders. Partner Abuse, 5(2), 189-203. doi: 10.1891/1946-6560.5.2.189

Hoyle, C. (2008). Will she be safe? A critical analysis of risk assessment in domestic violence cases. Children and Youth Services Review, 30131, 323-337. doi: 10.1016/i.childyouth.2007.10.009

Johnson, H. \& Conners, D. E. (2017). The benefits and impacts of mandatory charging in Ontario: Perceptions of abused women, service providers and police. University of Ottawa. https://ruor.uottawa. $\mathrm{ca} / \mathrm{bitstream} / 10393 / 37546 / 1 / \mathrm{MCP} \% 20$ Report\%20Final\%20 EN\%2014072017.pdf

Johnson, I. M., Sigler, R. T., \& Crowley, J. E. (1994). Domestic violence: A comparative study of perceptions and attitudes toward domestic abuse cases among social service and criminal justice professionals. Journal of Criminal Justice, 22(3), 237-248. doi: 10.1016/00472352(94)90020-5

Jung, S., \& Buro, K. (2017). Appraising risk for intimate partner violence in a police context. Criminal Justice and Behavior, 44(2), 240-260. doi: $10.1177 / 0093854816667974$

Kane, R. J. (1999). Patterns of arrest in domestic violence encounters: Identifying a police decision-making model. Journal of Criminal Justice, 2711), 65-79. doi: 10.1016/S0047-2352/98/00037-3

Kebbell, M. R. (2019). Risk assessment for intimate partner violence: How can the police assess risk? Psychology, Crime \& Law, 25(8), 829-846. doi: 10.1080/1068316X.2019.1597087

Kropp, R. (2004). Some questions regarding spousal assault risk assessment. Violence Against Women, 10(6), 676-697. doi: $10.1177 / 1077801204265019$

Lauria, I., McEwan, T. E., Luebbers, S. , Simmons, M., \& Ogloff, J. R. (2017). Evaluating the Ontario Domestic Assault Risk Assessment in an Australian frontline police setting. Criminal Justice and Behavior, 44(12), 1545-1558. doi: 10.1177/0093854817738280

McTague, J. (2018). Validation of the Ontario Domestic Assault Risk Assessment (ODARA) instrument with men and women [Master's thesis, University of New Brunswick]. ProQuest Dissertations and Theses database.

Mental Health Centre Penetanguishene (2005). Ontario Domestic Assault Risk Assessment: General scoring criteria. In collaboration with Ontario Provincial Police Behavioural Sciences Section.

Messing, J. T. (2007). Assessing the risk: What police reports reveal about domestic violence escalation [Doctoral dissertation, University of California, Berkley]. ProQuest Dissertations and Theses database.

Messing, J. T., \& Thaller, J. (2013). The average predictive validity of intimate partner violence risk assessment instruments. Journal of Interpersonal Violence, 28(7), 1537-1558. doi: 10.1177/0886260512468250

Messing, J. T., Thaller, J., Bagwell, M. (2014). Factors related to sexual abuse and forced sex in a sample of women experiencing policeinvolved intimate partner violence. Health \& Social Work, 39(3), 181-191. https://doiorg.proxyl.lib.uwo.ca/10.1093/hsw/hlu026

Milgram, A., Holsinger, A. M., Vannostrand, M., \& Alsdorf, M. W. (2015). Pretrial risk assessment: Improving public safety and fairness in pretrial decision making. Federal Sentencing Reporter, 27(4), 216-221. doi: $10.1525 /$ frr.2015.27.4.216 
Moser, A. E. (2012). Validation and expansion of the Ontario Domestic Assault Risk Assessment (ODARA) instrument: An early warning system [Master's thesis, University of New Brunswick]. ProQuest Dissertations and Theses database.

Poon, J., Dawson, M., \& Morton, M. (2014). Factors increasing the likelihood of sole and dual charging of women for intimate partner violence. Violence Against Women, 20(12), 1447-1472. doi: $10.1177 / 1077801214557954$

Robinson, A. L., Pinchevsky, G. M., \& Guthrie, J. A. (2018). A small constellation: Risk factors informing police perceptions of domestic abuse. Policing and Society, 28(2), 189-204. doi: 10/1080/ 10439463.2016 .1151881

Robinson, A. L., Myhill, A., Wire, J., Roberts, J., \& Tilley, N. (2016). Risk-led policing of domestic abuse and the DASH risk model. Cardiff University. https://whatworks.college.police.uk/Research/Documents/ Risk-led_policing_and_DASH_risk_model.pdf

Spivak, B., McEwan, T., Luebbers, S., \& Ogloff, J. (2020). Implementing evidence-based practice in policing family violence: The reliability, validity, and feasibility of a risk assessment instrument for prioritising police response. Policing and Society. doi: $10.1080 / 10439463.2020 .1757668$

Storey, J. E., Kropp, R. P., Hart, S. D., Belfrage, H., \& Strand, S. (2014). Assessment and management of risk for intimate partner violence by police officers using the brief spousal assault form for the evaluation of risk. Criminal Justice and Behavior, 41(2), 256-271. doi: 10.1177/0093854813503960

Storey, J. E., \& Strand, S. (2017). The influence of victim vulnerability and gender on police officers' assessment of intimate partner violence risk. Journal of Family Violence, 32(1), 125-134. doi: 10.1007/ s10896-016-9905-0

Tatum, K. M., \& Pence, R. (2015). Factors that affect the arrest decision in domestic violence cases. Policing: An International Journal, 38(1), 56-70. doi: 10.1108/pijpsm-07-2014-0075

Trujillo, M. P., \& Ross, S. (2008). Police response to domestic violence: Making decisions about risk and risk management. Journal of Interpersonal Violence, 23(4), 454-473. doi: 10.1177/0886260507312943

Ursel, J., Blaney, E., Dawson, M., Gill, C. \& Tutty, L. (2008). Canadian observatory tracking grid and code book. Fredericton: Canadian Observatory.

Ward-Lasher, A., Messing, J. T., \& Hart, B. (2017). Policing intimate partner violence: Attitudes toward risk assessment and collaboration with social workers. Social Work, 62(3), 211-218. doi: 10.1093/ sw/swxO23

Wormith, J. S., Hogg, S., \& Guzzo, L. (2012). The Predictive validity of general risk/needs assessment inventory on sexual offender recidivism and an exploration of the professional override. Criminal Justice and Behavior, 39(12), 1511-1538. doi: 10.1177/0093854812455741 